\title{
Effect of pH on Shoot Proliferation of Banana (Musa spp) with Constant BAP (mg/l)
}

\author{
Amruta A. Lahane, Pratiksha R. Khelge* and Abhijeet V. Chavan \\ Department of Plant Tissue Culture, MGM College of Agriculture Biotechnology (CABT) \\ Gandheli Aurangabad, India \\ *Corresponding author
}

\section{A B S T R A C T}

\section{Keywords}

Banana ,

Micropropagation,

Shoot, Growth,

Rooting

Article Info

Accepted:

07 October 2020

Available Online:

10 November 2020
A tissue culture technique for rapid clonal propagation and storage under minimal growth conditions is presented in this paper. Shoot-tip cultures of Musa Cultivator (both banana and plantain) are induced by culturing small excised shoot apices on modified MS semisolide medium supplements with various concentration and combination of auxins and cytocynins. The explants were selected from the field of Ishved Biotech PVT.LTD. Sindhkedraja Dist. Buldana for the experiments. Present investigation entitled "Effect of $\mathrm{pH}$ on shoot proliferation of banana (Musa sp.) with constant BAP (4mg/l)."There were five treatments of $\mathrm{pH}$ used in that experiments i.e $\mathrm{pH} 5.2,5.5,5.8,6.1,6.4$ and media prepared with different treatments of $\mathrm{pH}$ and with constant BAP. 1L media per treatment. BAP is constant $4 \mathrm{mg} / \mathrm{L}$. This media in bottles, and kept for incubation of one day. The healthy, disease free suckers as explants were selected for the experimentation. The sterilization of explants was done with different sterilization agents in with ethanol, ascorbic acid, mercuric chloride streptocyclin, tween -20 bavistin then inoculation of explants was done under laminar air flow. Inoculated bottles are transferred to growth room for growth are under controlled condition, temp is maintained $25+{ }_{-} 20 \mathrm{C}$ with $16 \mathrm{hr}$ photoperiod.

\section{Introduction}

A Banana is an edible fruit botanically a berry produced by several kinds of large herbaceous flowering plants in the genus Musa (anonymous 2018). Banana and plantains (Musa spp) are growing in more than 125 countries, primarily in tropical. Countries, thought the world. They are grown in a range of environmental condition with relatively minimum expenses for cultivation and produce fruits year round. They are amongst the 29 crop species on which people largely depend for most of their calories and protein (Borlang.1983). They are propagated vegetative as majority is seed less hybrid varieties. In India it is grown in 3, 96,000. Hectares, mainly in Tamil Nadu, west Bengal, Kerala, Maharashtra, Gujarat, Karnataka north eastern states etc. India is high production of Banana in the world 29.82 million tones i.e. contributing to $27 \%$ of world's banana production. Incidentally, production of banana in India has surpassed 
mango production (Kumar et al., 2003). Farmer in Southeast Asia and Papua New Guinea first domesticated bananas. Recent archaeological and paleontology environmental evidence at Kuk Swamp in the Western highlands province of Papua New Guinea suggests that banana cultivation there goes back to at least $5000 \mathrm{BCE}$, and possibly to 8000 BCE (Denham et al., 2003). Banana belongs to Kingdom Planate, family Musaceae Genus: Musa, Order: Zingiberales. Center of origin means the birthplace of a plant. According to available literature, the Indo Burma region is considered as the center of origin of banana. A number of wild varieties of banana were found from this region. Further studies also proved that the table variety of banana have originated in Malaysia. And the cooking variety is considered to be originated in South India. Banana cultivation is distributed throughout the world. Among the different banana cultivating countries, India ranks first both in area and production. The other major banana producing countries include Ecuador, Brazil, China, Philippines, Colombia, Indonesia, Costa Rica, Cameroon, Mexico etc. Coming to India, Tamil Nadu forms the state where the area and production of banana is the highest. The other major states include Maharashtra, Karnataka, Andhra Pradesh, Gujarat, Madhya Pradesh, Bihar, Assam, Kerala, West Bengal etc. in the order (Food and Agriculture Organization United Nations Database, 2012).

Tissue culture is a very fast technique. Thousands of plantlets can be produced in a few weeks time from a small amount of plant tissue. The new plants produced by tissue culture are disease free... Tissue culture can grow plants round the year, irrespective of weather or season... Very little space is needed for developing new plants by tissue culture. It helps to speed up the production of new varieties into the market place. In case of the seed potato industry, this technique helps in maintaining and establishing virus free stock. So, we have understood that tissue culture is a technique which is important for transforming plants with new gene (Bhosale et al., 2011)

By considering the above points the present investigation entitled Effect of $\mathrm{pH}$ on shoot proliferation on Banana (Musa acuminata) GGN with constant BAP was conducted at Ishved Biotech Pvt Ltd.

The main objectives of this study includes to find out optimum $\mathrm{pH}$ for maximum shoot proliferation of Banana and to study effect of increased $\mathrm{pH}$ Concentration on in-vitro rooting.

\section{Materials and Methods}

\section{Experimental site}

Ishved biotech Pvt. Ltd. Malsavargaon, Sindkhedraja dist. Buldana.

\section{Experimental Details}

Statistical design: Completely randomized design (CRD)

Number of treatment $=5$

Number of replication $=4$

\begin{tabular}{|c|c|}
\hline Treatments & $\mathbf{p H}$ \\
\hline $\mathbf{T}_{\mathbf{1}}$ & 5.2 \\
\hline $\mathbf{T}_{\mathbf{2}}$ & 5.5 \\
\hline $\mathbf{T}_{\mathbf{3}}$ & 5.8 \\
\hline $\mathbf{T}_{\mathbf{4}}$ & 6.1 \\
\hline $\mathbf{T}_{\mathbf{5}}$ & 6.4 \\
\hline
\end{tabular}

\section{Collection of explant}

Disease free and juvenile explants were collected from the field of the Ishved Biotecch Pvt. Ltd., Sindkhed Raja, Buldhana. 


\section{Explant selection}

Explants are cut into $10-12 \mathrm{~cm}$ size of banana 'GGN' cultivars which are selected from the collected suckers.

\section{Surface sterilization}

Collected suckers was cleaned under running tap water for about 15 to $20 \mathrm{~min}$. Anti-oxidant solution treatment was given to isolated nodal segments by soaking in antioxidant solution $(150 \mathrm{mg} / \mathrm{L})$ ascorbic acid and $(100 \mathrm{mg} / \mathrm{L}$ citric acid) for $20 \mathrm{~min}$. each under laminar air flow hood and followed by three times rinsing in sterile distilled water. Nodal segments will be further soaked in fungicide (M45) solution (1 $\mathrm{mg} / \mathrm{L}$ ) for $45 \mathrm{~min}$. and then again washed with sterile distilled water. Streptomycin solution $(100 \mathrm{mg} / \mathrm{L})$ treatment was also given to explants for $20 \mathrm{~min}$. and then washed by sterile distilled water and then $1 \mathrm{~g} / \mathrm{L}$ mercuric chloride solution for $10 \mathrm{~min}$. was used to treat these explants followed by three times washed with sterile distilled water for complete sterilization of nodal explants.

\section{Inoculation}

Completely sterilized explant was inoculated on establishment media. After establishing transferred explants on proliferation media for growth, completely proliferated explants was then transferred to rooting media.

\section{Culture media}

Culture media (MS medium) prepared for micropropagation of banana cultivar 'GGN' as a basal medium supplemented with organic acids and vitamins $\mathrm{pH}$ of prepared media was initial $\mathrm{pH} 5.3$ to adjusted upto 6.4. For proliferation stage media was adjusted for concentration as follows, BAP @ $4 \mathrm{mg} / \mathrm{L}$ for maximum shoot proliferation.

\section{Biometric observation}

Number of shoot initiation

Shoot length

Number of root

Root length

\section{Results and Discussion}

The result obtained in the present investigation on "Effect on $\mathrm{pH}$ on shoot proliferation on banana with constant BAP" was presented under the following headings.

\begin{tabular}{|c|c|}
\hline Treatments & $\mathbf{p H}$ \\
\hline & \\
\hline $\mathbf{T}_{\mathbf{1}}$ & 5.2 \\
\hline $\mathbf{T}_{\mathbf{2}}$ & 5.5 \\
\hline $\mathbf{T}_{\mathbf{3}}$ & 5.8 \\
\hline $\mathbf{T}_{\mathbf{4}}$ & 6.1 \\
\hline $\mathbf{T}_{\mathbf{5}}$ & 6.4 \\
\hline
\end{tabular}

Present investigation entitled "Effect of $\mathrm{pH}$ on shoot proliferation of banana (Musa sp.) with constant BAP $(4 \mathrm{mg} / \mathrm{l})$." was carried out invitro conditions during December 2019 May 2020 in tissue culture lab of Ishved Biotech pvt. ltd. Sindhkhed Raja, Buldhana, through MGM College of Agricultural Biotechnology, Gandheli, Aurangabad. Experiment was laid out in Completely Randomize Design with five treatments of $\mathrm{pH}$ concentrations $(5.2,5.5,5.8,6.1,6.4)$ in combination with constant (BAP $4 \mathrm{mg} / \mathrm{ltr}$ ) and four replications.

Media prepared with different treatments of $\mathrm{pH}$ and with constant BAP. 1 ltr media per treatment, BAP is constant $4 \mathrm{mg} / /$ tr. this media poured in bottles, and kept for incubation of 1 day (Fig. 1 - 10 and Table 1$3)$. 
Table.1 Effect on $\mathrm{pH}$ on shoot proliferation of Banana with constant BAP on number of shoot, shoot length and No. of roots, root length for 1culture

\begin{tabular}{|c|c|c|c|c|c|c|c|}
\hline \multirow[t]{2}{*}{ Sr.No. } & \multirow[t]{2}{*}{ Culture/Bottle } & \multirow[t]{2}{*}{ Crop Physiology } & \multicolumn{5}{|c|}{$\begin{array}{c}\text { Treatments } \\
\text { Different } \mathrm{pH} \text { with constant BAP }(4 \mathrm{mg} / \mathrm{l})\end{array}$} \\
\hline & & & 5.2 & 5.5 & 5.8 & 6.1 & 6.4 \\
\hline \multirow{4}{*}{1.} & \multirow{4}{*}{$\begin{array}{l}1 \text { culture/ bottle } \\
\text { (5Bottles) }\end{array}$} & No. of shoots & 6 & 9 & 6 & 12 & 8 \\
\hline & & Shoot length & $\begin{array}{c}2 \\
\mathrm{Cm}\end{array}$ & $\begin{array}{l}1.5 \\
\mathrm{~cm}\end{array}$ & $\begin{array}{c}4 \\
\mathrm{~cm}\end{array}$ & $\begin{array}{c}3 \\
\mathrm{Cm}\end{array}$ & $\begin{array}{c}2 \\
\mathrm{~cm}\end{array}$ \\
\hline & & No. of roots & 10 & 5 & 11 & 9 & 15 \\
\hline & & Root length & $\begin{array}{c}2 \\
\mathrm{~cm}\end{array}$ & $\begin{array}{c}5 \\
\mathrm{~cm}\end{array}$ & $\begin{array}{c}3 \\
\mathrm{~cm}\end{array}$ & $\begin{array}{c}5 \\
\mathrm{~cm}\end{array}$ & $\begin{array}{c}4 \\
\mathrm{~cm}\end{array}$ \\
\hline
\end{tabular}

Table.2 Effect of different $\mathrm{pH}$ and with constant BAP on number of shoot, shoot length and No. of roots, root length ( 2 culture bottles)

\begin{tabular}{|c|c|c|c|c|c|c|c|}
\hline \multirow[t]{2}{*}{ Sr.No. } & \multirow[t]{2}{*}{ Culture/Bottle } & \multirow[t]{2}{*}{ Crop Physiology } & \multicolumn{5}{|c|}{$\begin{array}{c}\text { Treatments } \\
\text { Different pH with constant BAP (4mg/l) }\end{array}$} \\
\hline & & & 5.2 & 5.5 & 5.8 & 6.1 & 6.4 \\
\hline \multirow{4}{*}{2.} & \multirow{4}{*}{$\begin{array}{l}\text { 2culture/ bottles } \\
\text { (10 Bottles) }\end{array}$} & No. of shoots & 6 & 10 & 7 & 12 & 15 \\
\hline & & Shoot length & $\begin{array}{c}2 \\
\mathrm{Cm}\end{array}$ & $\begin{array}{c}4 \\
\mathrm{~cm}\end{array}$ & $\begin{array}{c}1 \\
\mathrm{Cm}\end{array}$ & $\begin{array}{c}2 \\
\mathrm{Cm}\end{array}$ & $\begin{array}{c}2 \\
\mathrm{Cm}\end{array}$ \\
\hline & & No. of roots & 15 & 16 & 5 & 13 & 15 \\
\hline & & Root length & $\begin{array}{c}4 \\
\mathrm{~cm}\end{array}$ & $\begin{array}{c}5 \\
\mathrm{~cm}\end{array}$ & $\begin{array}{c}2 \\
\mathrm{~cm}\end{array}$ & $\begin{array}{c}5 \\
\mathrm{~cm}\end{array}$ & $\begin{array}{c}6 \\
\mathrm{~cm}\end{array}$ \\
\hline
\end{tabular}

Table.3 Effect on $\mathrm{pH}$ on shoot proliferation of Banana with constant BAP (4mg/l) for 3 culture Bottle

\begin{tabular}{|c|c|c|c|c|c|c|c|}
\hline \multirow[t]{2}{*}{ Sr. No. } & \multirow[t]{2}{*}{ Culture/Bottle } & \multirow[t]{2}{*}{ Crop Physiology } & \multicolumn{5}{|c|}{$\begin{array}{c}\text { Treatments } \\
\text { Different pH with constant BAP (4mg/l) }\end{array}$} \\
\hline & & & 5.2 & 5.5 & 5.8 & 6.1 & 6.4 \\
\hline \multirow{4}{*}{3.} & \multirow{4}{*}{$\begin{array}{c}3 \text { culture/ } \\
\text { bottles } \\
\text { (10 Bottles) }\end{array}$} & No.of shoots & 7 & 15 & 12 & 10 & 15 \\
\hline & & Shoot length & $\begin{array}{c}4 \\
\mathrm{Cm}\end{array}$ & $\begin{array}{c}3 \\
\mathrm{Cm}\end{array}$ & $\begin{array}{c}2 \\
\mathrm{Cm}\end{array}$ & $\begin{array}{c}2 \\
\mathrm{Cm}\end{array}$ & $\begin{array}{l}2.5 \\
\mathrm{Cm}\end{array}$ \\
\hline & & No.of roots & 20 & 20 & 8 & 12 & 14 \\
\hline & & Root length & $\begin{array}{c}5 \\
\mathrm{Cm}\end{array}$ & $\begin{array}{c}3 \\
\mathrm{Cm}\end{array}$ & $\begin{array}{c}3 \\
\mathrm{Cm}\end{array}$ & $\begin{array}{c}3 \\
\mathrm{Cm}\end{array}$ & $\begin{array}{c}3 \\
\mathrm{Cm}\end{array}$ \\
\hline
\end{tabular}


Fig.1 Days required for shoot initiation

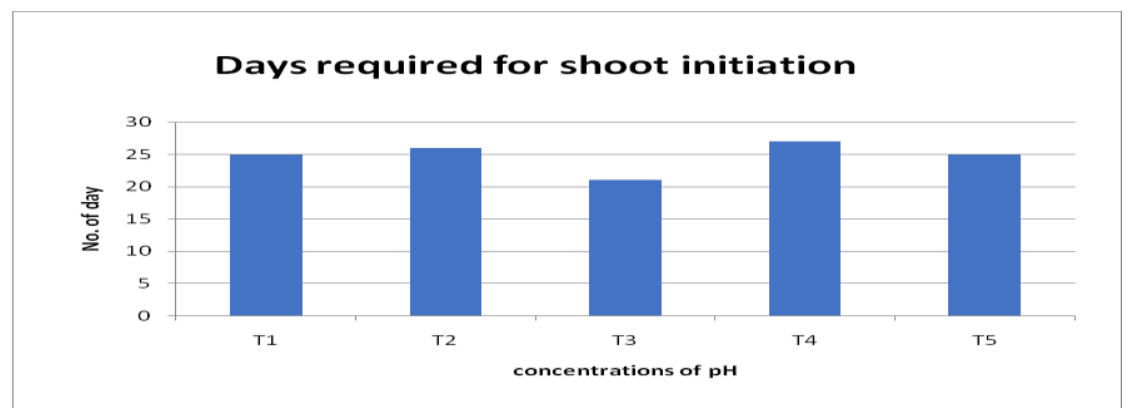

Fig.2 Effect on $\mathrm{pH}$ of shoot proliferation of Banana with constant BAP (4mg/l) for 1culture bottle

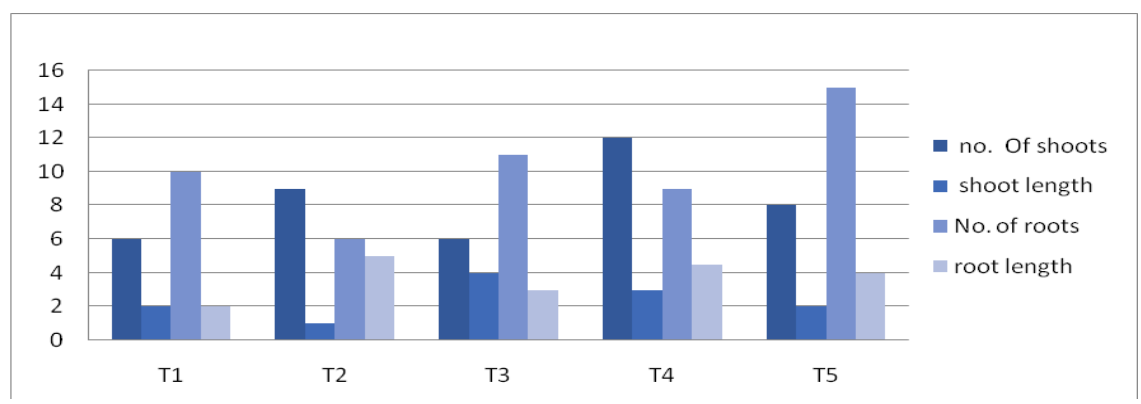

Fig.3 Effect on $\mathrm{pH}$ on shoot proliferation of Banana with constant BAP $(4 \mathrm{mg} / \mathrm{l})$ for 2 culture bottles

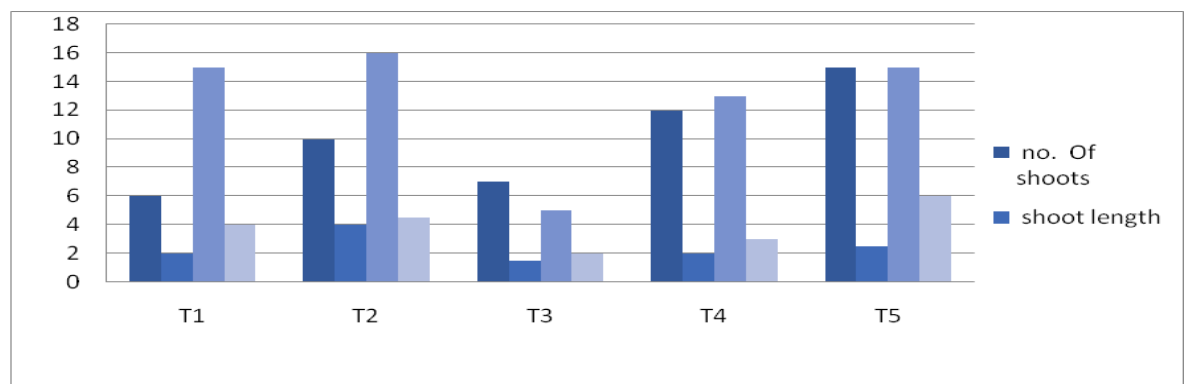

Fig.4 Effect of different concentrations of NAA and with constant BAP on number of shoot, shoot length and No. of roots, root length (3culture bottles

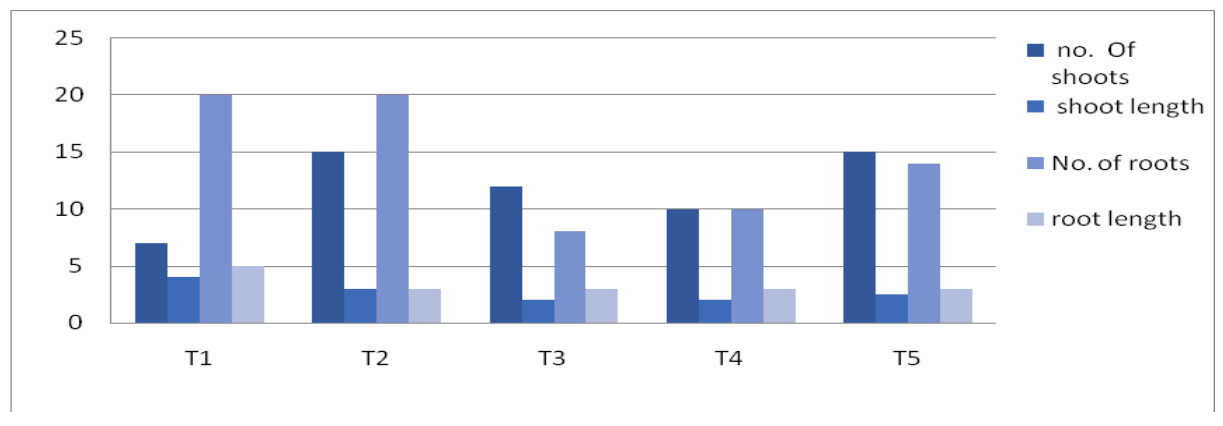


Fig.5 Inoculation of sucker explants of Banana

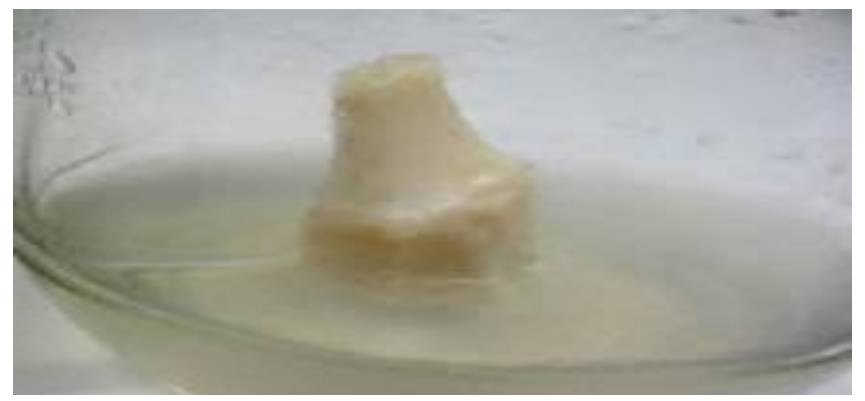

Fig.6 Shoot initiation after 21 days

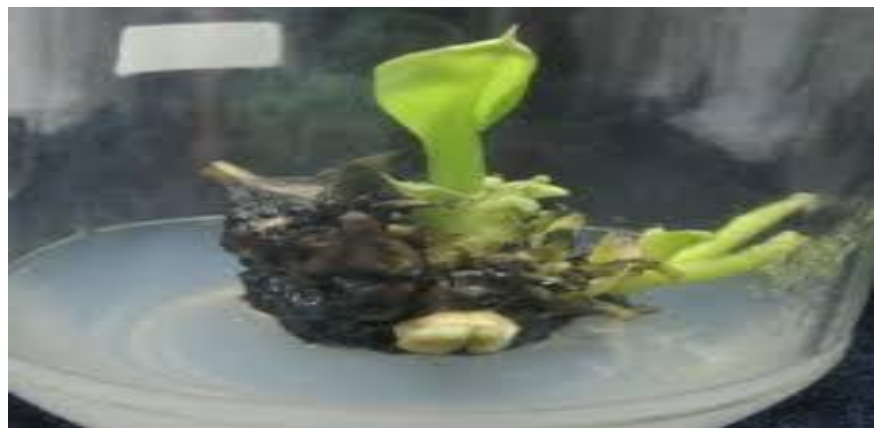

Fig.7 Effect of pH 6.1 on Shoot Proliferation of Banana with constant BAP (4mg/l)

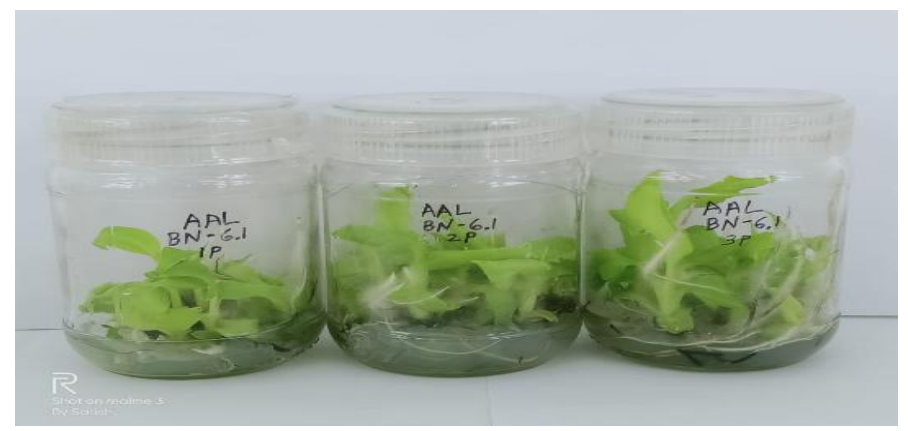

Fig.8 Effect of different $\mathrm{pH}$ on Shoot Proliferation of Banana with constant BAP (4mg/l))

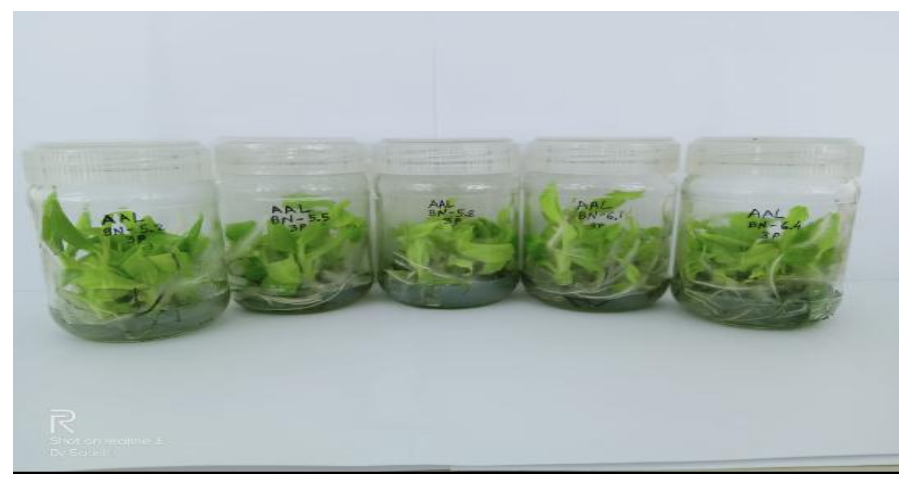


Fig.9 Shoot Proliferation of Banana plant

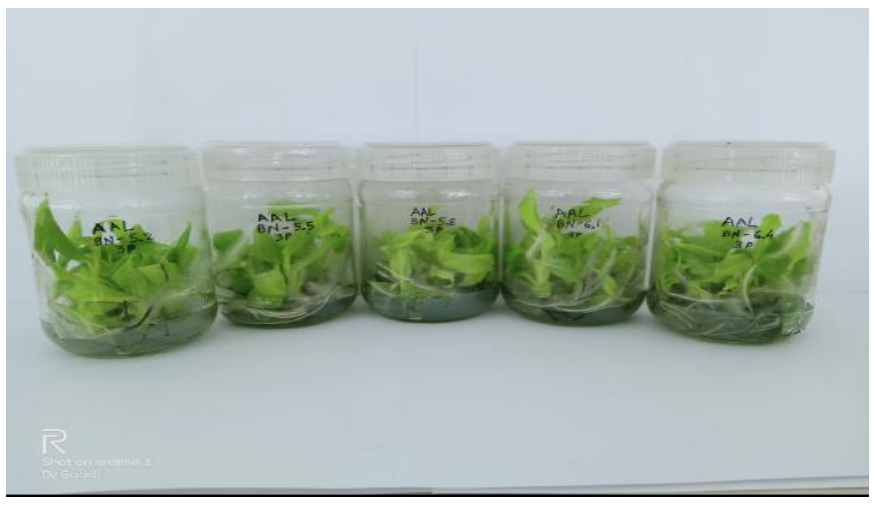

Fig.10 Effect of increasing $\mathrm{pH}$ on roots

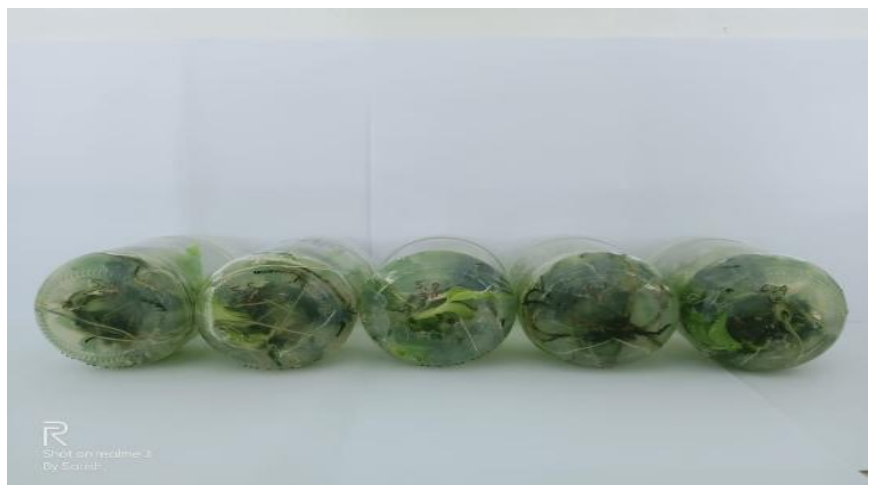

The healthy, disease free, suckers as explants were selected for the experimentation. The explants were collected from the field of Ishved Biotech pvt. 1td., leaf and stem of suckers is removed cut into $8-10 \mathrm{~cm}$, are washed several time with tap water for 15 to $20 \mathrm{~min}$ and suckers are trimmed. Under laminar air flow layers are removed and cut into $4-6 \mathrm{~cm}$ pieces then this suckers are dipped in T20 solution for $15-20 \mathrm{~min}$. After that suckers given 3 wash of distilled water. Then $1 \%$ bavistine treatment is given for $30 \mathrm{~min}$, again 3 wash of autoclaved distilled water. $70 \%$ ethanol treatment given for $1 \mathrm{~min}$, again 3 washes of autoclaved distilled water repeated. $0.1 \%$ mercuric chloride treatment given for $15 \mathrm{~min}$, again 3 washes of autoclaved distilled water are repeated. Then finally suckers are trimmed into $2-3 \mathrm{~cm}$. This explants are inoculated in the incubated media bottles in three patterns 5 bottles of 1 culture, 10 bottles of 2 culture, 10 bottles of 3 culture.

Inoculated bottles are transferred to growth room for growth under controlled condition, temperature is maintained at $25 \pm 2^{\circ} \mathrm{C}$ with 16 hour photo period.

Present investigation showed best growth of roots and shoots at treatment 4 with $\mathrm{pH} 6.1$ with constant $(4 \mathrm{mg} / \mathrm{ltr}) \mathrm{BAP}$, as compared to other concentrations.

\section{References}

Agnishwar by In vitro shoot tip culture. International J. Biotechnol vol. 4(4) pp. 83-88. Chavan, V. B., Arekar, C. D. and Gaikwad, D. K. 2010. Field performance of in vitro propagated 
banana plants from 8th and 15th subculture. International Journal of Advanced Biotechnology and Research., 1(2): 96-103.

Al-amin M, Karim M., Amin M., Rahman S. and Mamun ANM 2009. In vitro micropropagation of banana (Musa spp.). Bangladesh J. Agric. Res. 34(4):645-659.

Al-amin MD., Karim M. R., Amin M. R., Rahman S. And Mamun A. N. M.
2009. Invitro micro propagation of banana (Musa spp.). Bangladesh J. Agril. Res. 34(4): pp. 645-659.

Shirani S., M. Fatemeh and M. Maziah. 2009. Morphological abnormality among regenerated shoots of banana and plantain (Musa spp.) after in vitro multiplication with TDZ and BAP from excised shoot-tips. Afr. J. Biotechnol., 8: 5755-5761.

\section{How to cite this article:}

Amruta A. Lahane, Pratiksha R. Khelge and Abhijeet V. Chavan. 2020. Effect of pH on Shoot Proliferation of Banana (Musa spp) with Constant BAP (mg/l). Int.J.Curr.Microbiol.App.Sci. 9(11): 682-689. doi: https://doi.org/10.20546/ijcmas.2020.911.083 